\title{
Pelatihan Multimedia bagi Guru dalam Menunjang Pembelajaran Daring
}

\author{
Harlinda Syofyan $^{1 *}$, Ratnawati Susanto ${ }^{2}$, M. Bahrul Ulum ${ }^{3}$ iD \\ 1,2,3 Pendidikan Guru Sekolah Dasar, FKIP, Universitas Esa Unggul Jakarta \\ ${ }^{3}$ Teknik Informatika, Fakultas Ilmu Komputer, Universitas Esa Unggul Jakarta \\ *Corresponding author: soflynda@esaunggul.ac.id
}

\section{Abstrak}

Pandemi covid-19 mengakibatkan proses belajar mengajar di Indonesia harus dilaksanakan secara online/daring. Hal seperti ini terjadi di SDN 1 Jelambar Baru, sekolah negeri yang berada di wilayah Jakarta Barat. Situasi pembelajaran daring menimbulkan tantangan dan permasalahan bagi guru dan siswa. Berdasarkan hasil identifikasi terdapat permasalahan yaitu tuntutan dan kebutuhan guru untuk meningkatkan keterampilannya dalam membuat media untuk mendukung pembelajaran online di masa pandemi COVID-19. Untuk mengatasi permasalahan tersebut, solusi yang telah diusulkan adalah dengan mengadakan pelatihan pembuatan bahan ajar multimedia. Metode yang digunakan dalam kegiatan ini adalah sosialisasi, pelatihan, refleksi diri, dan simulasi. Hasil yang diperoleh dari kegiatan PKM ini adalah: (1) kesesuaian materi dengan yang diinginkan oleh guru SDN Jelambar Baru 01, (2) mendapat respon positif dari guru dengan bukti kehadiran $100 \%$ dan kegiatan interaktif 67\%, dan, (3) beberapa peserta memahami materi yang telah disampaikan dan yang ditandai dengan peningkatan penggunaan penggunaan power point $7 \%$, Google Meet $7 \%$, Props $40 \%$, dan video snimation sebesar $25 \%$.

Kata Kunci: Multimedia, Pembelajaran Daring, Covid-19

\section{Abstract}

The COVID-19 pandemic has forced the teaching and learning process to be carried out online in Indonesia. As happened in SDN Jelambar Baru 01, a public school located in the West Jakarta area. Online learning situations pose challenges and problems for both teachers and students. Referring to the problems that have been identified, including the demand and need for teachers to improve their skills in making media to support online learning during the COVID-19 pandemic. To overcome these problems, the solution that has been proposed is to conduct training in making multimedia teaching materials. The methods used are socialization, training, self-reflection, simulation. The results obtained from this PKM activity are; (1) There is conformity of the material with what the teachers of SDN Jelambar Baru 01 want; (2) Getting a positive response from the teacher with evidence of $100 \%$ attendance and $67 \%$ interactive activities; (3) Some participants understand the material that has been delivered and, which is marked by an increase in the use of using PowerPoint 7\%, Google Meet 7\%, Props 40\%, and Video Animation by $25 \%$.

Keywords: Multimedia, Online Learning, COVID-19

\section{PENDAHULUAN}

Pandemi yang diakibatkan oleh virus covid-19 ini bukan hanya terjadi di Indonesia tetapi di seluruh dunia pun mengalami masa pandemicovid-19 (Khasanah et al., 2020; Novayulianti, 2021). Masa pandemi ini memberikan dampak pada bidang pendidikan khususnya siswa, guru, dan sekolah. Keadaan seperti ini mengharuskan siswa dan guru melakukan proses belajar mengajar secara online (Purwanto et al., 2020; Syofyan \& Yuliana, 2020). Hal ini dilakukan untuk mengurangi interaksi antarorang karena wabah ini membahayakan. Hal tersebut dilakukan untuk memperkecil penyebaran virus covid-19 ini (Firman \& Rahayu, 2020; Lestari \& Syofyan, 2021). Pada saat melakukan pembelajaran daring ini guru memerlukan sebuah multimedia yang dapat menunjang pembelajaran. Untuk

$\begin{array}{ll}\text { History: } & \\ \text { Received } & \text { : September 10, } 2021 \\ \text { Revised } & \text { : September 12, } 2021 \\ \text { Accepted } & \text { : November 19, } 2021 \\ \text { Published } & \text { : November } 25,2021\end{array}$


itu, guru harus dapat membuat sebuah multimedia yang menarik dalam memberikan pembelajaran kepada siswa. Multimedia merupakan sebuah media belajar dengan menggunakan TIK (Teknologi Informasi dan Komunikasi) yang di dalamnya dapat berupa sebuah gambar, animasi, teks, dan audio (Marisda, 2020; Marjuni \& Harun, 2019). Penggunaan multimedia selama pembelajaran daring ini sangat penting karena dengan guru menggunakan multimedia akan terbantu dalam menyampaikan materi pelajaran yang dibahas. Selain itu, dengan menggunakan multimedia selama pembelajaran daring ini akan memberikan kemudahan bagi siswa dalam memahami materi pelajaran yang dibahas.

Selama pelaksanaan pembelajaran secara daring, siswa dan guru sangat memerlukan bantuan alat teknologi seperti handphone, laptop, atau pun komputer. Selain alat teknologi tersebut diperlukan juga kuota internet yang memadai untuk mengakses materi atau tugastugas yang guru berikan. Guru memiliki peran penting untuk membuat siswa tertarik dalam mengikuti pembelajaran daring ini (Poerwanti \& Mahfud, 2018; Putri \& Syofyan, 2019). Untuk itu, guru harus dapat membuat sebuah multimedia yang menarik dengan menggunakan aplikasi-aplikasi yang menarik yang membuat siswa lebih tertarik dalam mengikuti pembelajaran. Ada banyak aplikasi-aplikasi yang dapat guru gunakan untuk membuat sebuah media.

Namun, tidak semua guru tahu aplikasi-aplikasi yang ada dan juga tidak semua guru mengerti akan penggunaan multimedia ini. Begitupun yang terjadi pada guru-guru di SDN Jelambar Baru 01. Guru-guru di SD tersebut masih mengalami kesulitan dalam pembuatan sebuah media belajar. Hal tersebut terlihat dari media yang digunakan sebagai alat untuk menyampaikan materi pelajaran hanya menggunakan aplikasi-aplikasi seperti google form, powerpoint dan juga google meet. Oleh karena itu, sangat dibutuhkan sebuah pelatihan pembuatan media belajar. Jika guru hanya menggunakan media seperti google form, powerpoint dan juga google meet, semakin lama siswa menjadi tidak tertarik mengikuti pembelajaran.

Dari hasil wawancara dengan kepala sekolah, guru, dan tenaga tata usaha, ditemui persoalan-persoalan yang dihadapi oleh SDN Jelambar Baru 01 yang dapat diidentifikasikan sebagai berikut. Pihak manajemen sekolah sangat membutuhkan pendampingan dan kerja sama dari pihak eskternal yang mencakup manajemen sekolah, kepemimpinan, supervisi, mentoring, coaching, dan lain sebagainya. Masalah lainnya adalah diperlukan pemahaman cara mengintegrasikan media dan sumber belajar secara by design atau by utilization dengan segala keterbatasan daya dukung sekolah dan sosial ekonomi orang tua. Masalah lainnya adalah perlu penyegaran pengembangan bahan ajar yang menarik bagi peserta didik sebagai pelayanan yang optimal melalui proses kegiatan bejalar yang menyenangkan. Hal ini dilaksankan sekaligus memberikan peningkatan proses pembelajaran. Dengan meningkatkan kemampuan professional guru dalam pengelolaan pembelajaran yang lebih baik dan menarik, maka tujuan yang diharapkan dalam pembelajar tercapai. Dan masalah terakhir perlu peningkatan penguasaan teknologi informasi bagi guru untuk menunjang kegiatan belajar mengajar dengan memberikan pembelajaran yang inovatif dan interaktif.

Berdasarkan masalah yang telah dianalisis sebelumnya dilaksanakanlah kegiatan pengabdian ini. Pengabdian yang yang telah diusulkan adalah dengan mengadakan pelatihan pembuatan bahan ajar multimedia. Metode yang digunakan dalam kegiatan ini dilakukan secara bertahap, yakni diawali dengan sosialisasi, kemudian pelatihan, refleksi diri, dan simulasi. Tujuan kegiatan ini di antaranya guru guru SDN 1 Jelambar Baru memiliki materi sesuai dengan yang diinginkan, guru mampu menciptakan pembelajaran yang lebih inovatif, dan yang terakhir peserta memahami materi yang telah disampaikan dan mampu menguasai media tersebut. 


\section{METODE}

Kegiatan pengabdian ini dilaksanakan melaui zoom meeting. Peserta atau sasaran dari kegiatan pengabdian ini adalah kepala sekolah dan seluruh guru SDN 1 Jelambar Baru. Peserta sangat antusias dalam kegiatan ini. Metode yang digunakan dalam kegiatan pelatihan ini yaitu sosialisasi, pelatihan, refleksi diri, simulasi, atau praktik. Metode pelaksanaan yang digunakan terlihat pada Gambar 1.

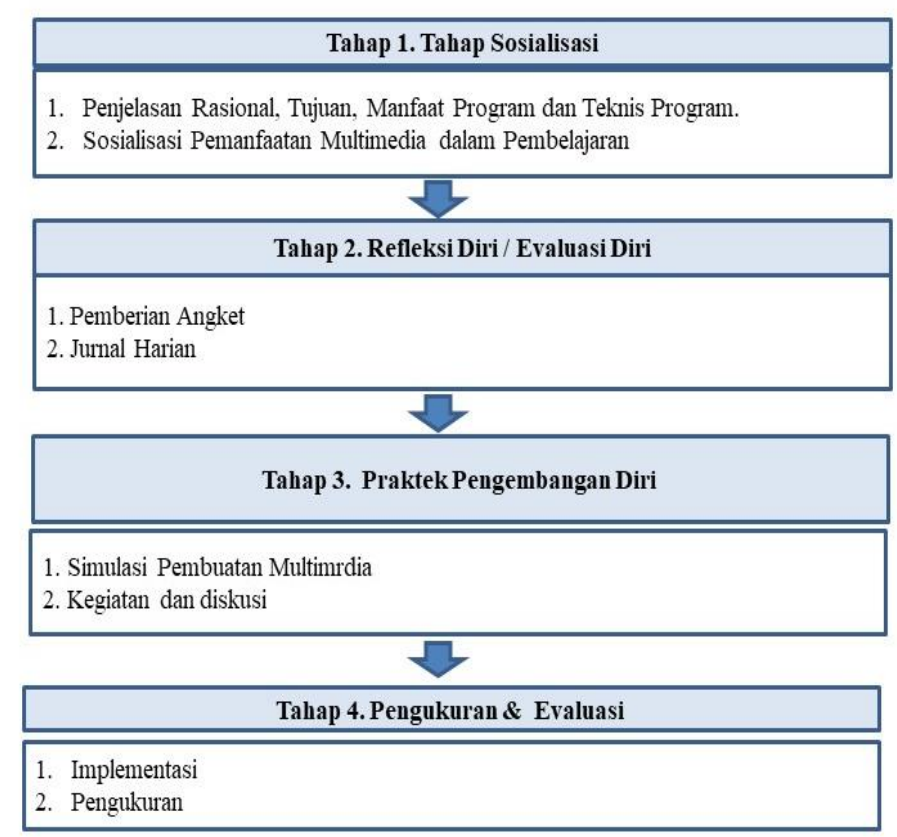

Gambar 1 Metode Pelaksanaan

Gambar 1 menjelaskan bahwa pada tahap 1 sosialisasi, tim melakukan sosialisasi kepada mitra mengenai tujuan dilakukan kegiatan ini, manfaat dari kegiatan, dan juga melakukan sosialisasi mengenai manfaat dari penggunaan multimedia dalam pembelajaran. Pada tahap 2 refleksi diri, tim menyebarkan sebuah kuesioner kepada guru-guru di SDN 1 Jelambar Baru menggunakan google formulir. Google formulir tersebut berisi pertanyaanpertanyaan terkait dengan pelatihan yang diinginkan oleh guru-guru di SDN 1 Jelambar Baru. Tahap 3 praktik, setelah tim mengetahui pelatihan mengenai multimedia dalam pembelajaran yang diinginkan selanjutnya tim melakukan pelatihan lewat zoom meeting dengan guru-guru di SD tersebut. Dalam kegiatan pelatihan ini, tim melakukan simulasi pembuatan sebuah multimedia yang menarik yang dapat guru gunakan selama pembelajaran daring ini. Setelah melakukan simulasi, tim memberikan kesempatan kepada guru-guru untuk bertanya. Tahap 4 pengukuran dan evaluasi, setelah selesai melakukan pelatihan, tim kembali menyebar kuesioner menggunakan google formulir. Kuesioner disebar untuk mengetahui harapan guru-guru setelah mengikuti kegiatan pelatihan ini.

\section{HASIL DAN PEMBAHASAN}

\section{Hasil}

\section{Kontribusi Mitra}

Kontribusi mitra pada pelaksanaan PKM ini dapat dikatakan sangat mendukung. Hal ini dapat digambarkan dalam kegiatan yang dilakukan melaui zoom meeting. Tim mitra sangat antusias dalam kegiatan ini. Selain dihadiri oleh kepala sekolah, kegiatan ini juga 
dihadiri oleh seluruh guru pada tim mitra. Dalam hal ini kontribusi mitra dalam kegiatan ini tercatat $100 \%$. Dalam kegiatan sesi tanya jawab pun mereka aktif bertanya untuk menggali kegunaan fitur-fitur dalam aplikasi yang disampaikan oleh tim PKM, baik yang disampaikan topik Augmented Realitity maupun untuk topik Aplikasi Video dalam pembelajaran. Lebih kurang sepuluh pertanyaan yang diajukan terkait pertanyaan fitur dan teknis penggunaan di lapangan, pembuatan, serta tips yang harus diketahui dalam membuat sebuah media yang baik. Dari total jumlah guru yang hadir $71 \%$ mengajukan pertanyaan dalam kegiatan ini. Hal ini menunjukkan bahwa guru sebagai pelaku dan pelaksana dari kegiatan pembelajaran ingin menampilkan dan membuatkan media yang beragam dan menarik untuk peserta didiknya. Selain itu, mereka juga meminta hasil rekaman kegiatan untuk melihat kembali penjelasan agar pada saat membuat media mereka memiliki panduan untuk menyelesaikan media yang dibuat. Materi yang disampaikan tetap dikirimkan ke mitra PKM agar mereka tetap mengakses materi yang diberikan. Untuk melihat tingkat kehadiran dan partisipasi aktif tim mitra dalam kegiatan ini disajikan dalam bentuk persentase kehadiran pertanyaan yang muncul dapat disajikan dalam Gambar 2.

Pada saat melaksanakan pembelajaran, guru memiliki peran penting untuk membuat pembelajaran yang menarik bagi siswa, sehingga akan meningkatkan ketertarikan siswa dalam mengikuti pembelajaran (Nurrita, 2018; Ratih \& Syofyan, 2021). Untuk membuat pembelajaran yang menarik, guru memerlukan bantuan media belajar yang menunjang pembelajaran yang akan dilaksanakan. Selain itu, media belajar digunakan guru untuk mengatasi kebosanan siswa dalam pembelajaran sehingga disadari sangat membantu guru untuk memberikan pemahaman kepada siswa. Media belajar ialah suatu alat yang digunakan untuk menyalurkan informasi kepada penerimanya dalam proses pembelajaran berlangsung (Atsani, 2020; Yuliani H \& Winata, 2017). Penggunaan media belajar di sekolah sangat baik karena dapat membantu seseorang dalam belajar. Media belajar adalah media yang dapat digunakan untuk mencapai tujuan pembelajaran dan juga akan mengakomodasi gaya belajar auditori dan visual peserta didik (Rachmawati \& Sojanah, 2019; Xie et al., 2019).

Guru dapat menggunakan media belajar berbasis multimedia interaktif. Multimedia interaktif merupakan sebuah media belajar dengan menggunakan TIK (Teknologi Informasi dan Komunikasi) yang di dalamnya dapat berupa sebuah gambar, animasi, teks, dan audio (Marisda, 2020; Praheto et al., 2020). Guru dapat membuat sebuah multimedia interaktif yang menarik untuk membantu guru dalam memberikan pembelajaran. Selain itu, diperlukan tampilan-tampilan materi agar memudahkan siswa dalam mempelajari materi yang diberikan (Baquier Orozco et al., 2020; Gunawan et al., 2019). Apalagi di masa pandemi seperti saat ini sangat dibutuhkan sebuah media belajar untuk membantu guru dalam memberikan pembelajaran kepada siswa. Dengan begitu guru harus memiliki kemampuan dan keterampilan dalam membuat sebuah media belajar yang menarik bagi siswa.

\section{Refleksi Kemampuan Pembuatan Multimedia sebelum Kegiatan}

Pada saat pembelajaran secara online, penggunaan sebuah media belajar dapat membantu siswa cepat dan mudah dalam memahami suatu pelajaran yang dibahas (Novita et al., 2019; Rafiuddin et al., 2017). Tetapi, sangat disayangkan masih banyak guru-guru yang kurang paham dalam menggunakan atau memanfaatkan media berbasis TIK (Teknologi Informasi dan Komunikasi). Begitu pun guru-guru di SDN Jelambar Baru 01 hampir 70\% guru di sekolah tersebut belum mengenal aplikasi media interaktif. Hal tersebut terlihat dari survei yang dilakukan oleh tim pelatihan. Dengan demikian, sangat perlu pelatihan kepada guru-guru agar dapat menggunakan atau memanfaatkan media belajar berbasis TIK ini. Data penggunaan media pembelajaran yang sering digunakan pada saat pandemic tersaji dalam Tabel 1. 
Tabel 1. Penggunaan Media Pembelajaran Sebelum Pelatihan

\begin{tabular}{cccccc}
\hline Responden & Power Point & Google Meet & Google Formulir & Alat Peraga & Video Animasi \\
\hline Guru & 12 & 14 & 14 & 2 & 1 \\
Persentase & $80 \%$ & $93 \%$ & $93 \%$ & $13 \%$ & $7 \%$ \\
\hline
\end{tabular}

Dari hasil survei yang dilakukan dengan menyebarkan sebuah pertanyaan melalui google formulir kepada guru-guru SDN Jelambar Baru 01 mengenai media belajar apa saja yang digunakan oleh guru-guru tersebut pada saat melakukan pembelajaran online didapatkan hasil bahwa rata-rata guru di SD tersebut melakukan pembelajaran dengan menggunakan powerpoint, google meet dan google formulir. Hal tersebut dapat dilihat pada Gambar 3.

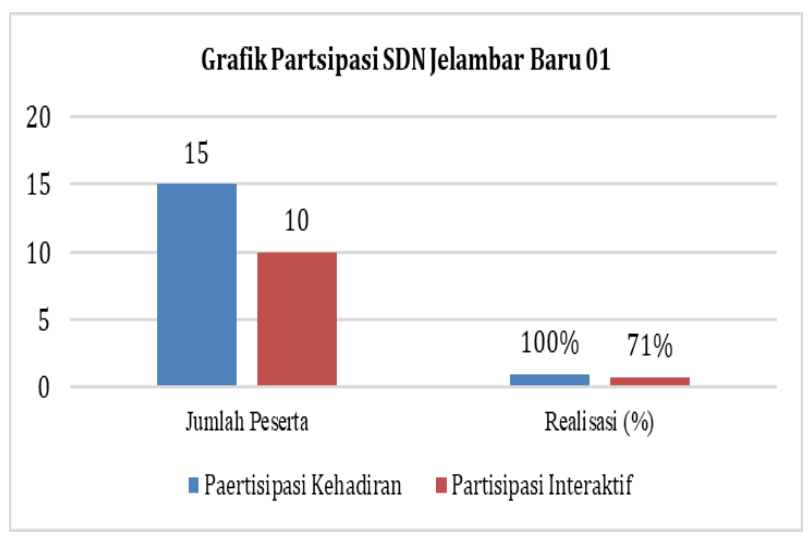

Gambar 2. Partisipasi Tim Mitra

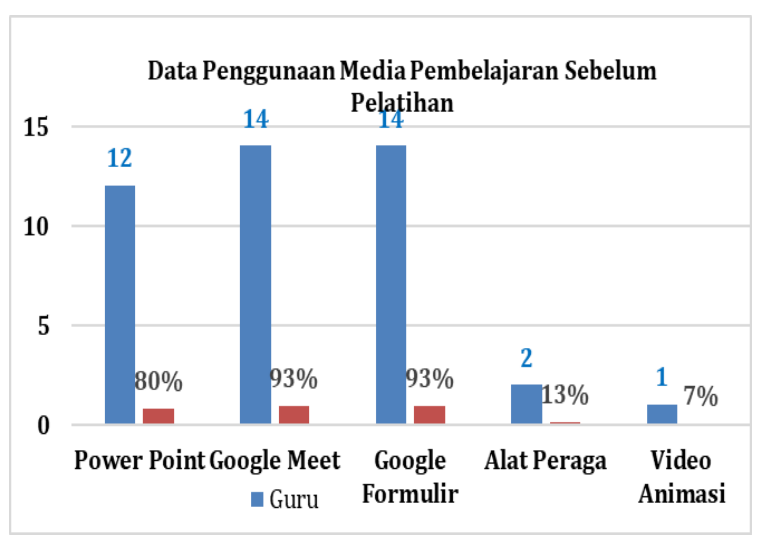

Gambar 3. Penggunaan Media Pembelajaran Sebelum Pelatihan

Guru di SDN 1 Jelambar Baru ini berjumlah 15 orang. Dari gambar 3 dapat diketahui dari 15 guru yang mengajar di SD tersebut, media yang paling banyak digunakan ialah media google meet, google formulir, dan powerpoint. Selain itu juga, sebelum diadakan kegiataan pelatihan ini, tim melakukan survei terkait dengan pelatihan apa yang diinginkan oleh guruguru di SDN 1 Jelambar Baru. Dari hasil survei tersebut didapat bahwa sebagaian besar guruguru menginginkan pelatihan membuat sebuah video animasi dan membuat powerpoint yang lebih menarik menggunakan animasi-animasi. Maka dengan begitu diadakan kegiatan pelatihan kepada guru-guru SDN 1 Jelambar Baru mengenai pembuatan multimedia interaktif untuk menunjang selama pembelajaran online. Kegiatan pelatihan pembuatan multimedia bagi guru dalam menunjang pembelajaran pada masa pandemi covid-19 diberikan kepada guru-guru di SDN 1 Jelambar Baru. Kegiatan pelatihan ini dilaksanakan pada tanggal 28 juli 2021 menggunakan aplikasi zoom meeting. Kegiatan pelatihan berjalan dengan lancar. Tim pelaksana pelatihan disambut dengan baik oleh guru-guru dan kepala sekolah SDN 1 Jelambar Baru.

\section{Refleksi Kemampuan Pembuatan Multimedia setelah Kegiatan}

Kegiatan PKM yang sudah dilakukan di SDN 1 Jelambar Baru, kemudian diambil data kembali dengan menggunakan kuesioner. Diperoleh data yakni 63\% guru di sekolah tersebut belum mengenal aplikasi media video animasi berbasis aplikasi, 53\% sudah menggunakan alat peraga, 93\% sudah menggunakan google formulir, 100\% menggunakan google meet, dan $87 \%$ juga sudah menggunakan power point. Hal tersebut terlihat dari survei 
yang dilakukan oleh tim pelatihan. Dengan demikian, sangat perlu pelatihan kepada guruguru agar apat menggunakan atau memanfaatkan media belajar berbasis TIK ini. Data penggunaan media pembelajaran yang sering digunakan pada saat pandemi tersaji dalam Gambar 4.

Dari data di gambar 4 dapat dikatakan bahwa pelatihan untuk pembuatan alat peraga, video animasi berbasis aplikasi, dan power point dengan hyperlink perlu dilakukan untuk kegiatan selanjutnya. Hal ini menjadi catatan bagi tim PKM untuk melaksanakan pelatihan lanjutan pada kesempatan yang akan datang. Sesuai dengan saran dan permintaan dari sekolah mitra hampir seluruh guru meeminta hal yang sama. Ternyata mereka memiliki keinginan yang kuat untuk menghadirkan pembelajaran yang bermakna dan menarik bagi peserta didik tentunya. Perlu dilakukan rancangan kegiatan lanjutan untuk pelatihan pembuatan multimedia ini dan diperlukan jadwal kegiatan yang harus disepakati kembali oleh pihak sekolah mitra. Untuk itu, memotivasi diri untuk memberikan yang terbaik bagi siswa merupakan wujud profesionalisme guru dalam melaksanakan pembelajaran. Dengan membuat dan menghadirkan pembelajaran yang menggunakan video interaktif, inovatif tentu akan menghasilkan pembelajaran yang efektif dan berimbas kepada hasil belajar yang baik sesuai dengan tujuan pembelajaran yang seharusnya (Syofyan \& Ismail, 2018; Wardani \& Syofyan, 2018).

\section{Peningkatan Penggunaan dan Pembuatan Media Pembelajaran}

Kegiatan PKM pelatihan pembuatan multimedia bagi guru dalam menunjang pembelajaran di masa pandemi ini menunjukkan hasil yang cukup menggembirakan. Pembuatan alat peraga dan video animasi dipandang sebagian guru membutuhkan waktu dan kesempatan yang cukup untuk membuatnya, tetapi mereka sudah berusaha walaupun peningkatannya sangat sedikit. Mereka sudah terispirasi untuk meningkatkan kualitas pembelajaran melalui penggunaan media. Hal ini tersaji dalam Gambar 5.

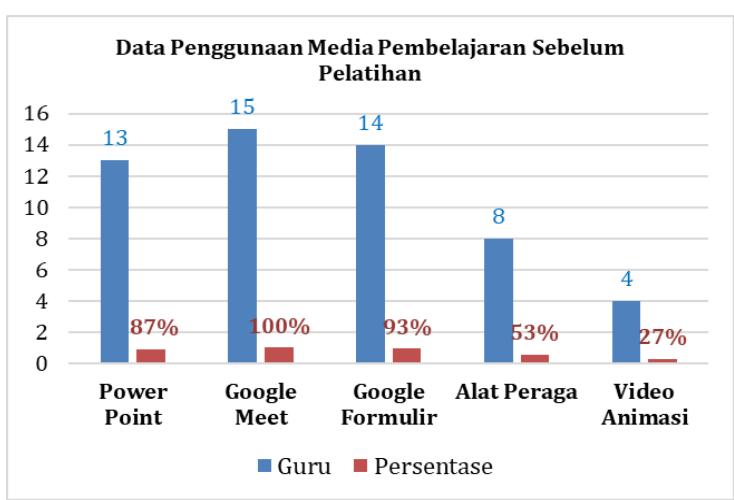

Gambar 4. Penggunaan Media Pembelajaran Setelah Pelatihan

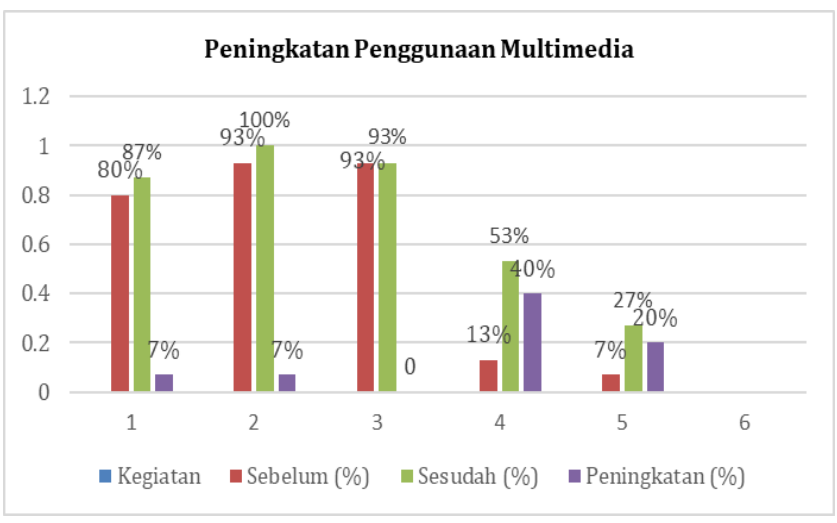

Gambar 5. Peningkatan Penggunaan Media

Gambar 5 menunjukkan bahwa penggunaan power point dan google meet meningkat sebesar $7 \%$, alat peraga meningkat sebesar $40 \%$, dan penggunaan video animasi meningkat 20\%. Ini berarti bahwa kegiatan PKM ini cukup berhasil, paling tidak ada keinginan dan kemauan guru untuk meningkatkan kualitas pembelajaran melalui penggunaan media. Harapannya, aktivitas dan kemampuan belajar siswa juga meningkat. Apalagi ketika pandemi seperti sekarang ini sangat dibutuhkan kreativitas dan kesediaan guru untuk melakukan adaptasi teknologi dalam menyukseskan pembelajaran; (Apak \& Taat, 2018; Lestari \& Harlinda, 2021; Sinta \& Sofyan, 2021). Selain itu, penerapan multimedia dalam pembelajaran juga dapat meningkatkan hasil belajar dari peserta didik karena mereka akan lebih paham 
dengan materi yang disampaikan (Cucus \& Aprilinda, 2016; Werdiningsih et al., 2019). Sejalan dengan hal tersebut, pembelajaran yang memanfaatkan multimedia juga dapat meningkatkan motivasi serta kemampuan berpikir kritis siswa dalam memecahkan masalahmasalah (Parameswari \& Kurniyati, 2020; Sari \& Sugiyarto, 2015). Hal ini juga sekaligus untuk mengembangkan inovasi pembelajaran yang dilakukan oleh guru dalam menunjang pembelajaran yang mereka bawakan (Kurniawati \& Nita, 2018; Rachmadtulla et al., 2019). Dengan diadakannya pelatihan ini, kepala sekolah dan guru-guru SDN 1 Jelambar Baru berharap akan dapat mengimplementasikannya dalam kegiatan pembelajaran. Di samping itu, mereka berharap dapat membuat sebuah media belajar yang lebih baik lagi yang digunakan pada saat pembelajaran.

\section{SIMPULAN DAN SARAN}

Kegiatan pelatihan ini diapresiasi dan disambut baik oleh guru-guru di SDN 1 Jelambar Baru. Semua guru tertarik mengikuti kegiatan ini karena materi yang disampaikan sesuai dengan keinginan pelatihan yang diharapkan oleh guru-guru yaitu pembuatan sebuah multimedia yang interaktif dan juga pembuatan powerpoint lebih menarik. Kegiatan pelatihan ini berhasil ditunjukkan dengan adanya kesesuaian antara materi dan keinginan guru-guru SDN 1 Jelambar Baru. Selain itu, pelatihan ini mendapat respon yang baik dan positif dari Duru-guru SDN 1 Jelambar Baru. Hal ini dibuktikan dengan kehadiran peserta 100\% serta aktivitas interaktif $71 \%$ oleh peserta. Keberhasilan kegiatan ini juga dibuktikan dengan banyak peserta yang memahami materi yang telah disampaikan dan akan diimplementasikan. Hal ini dibuktikan dengan terjadinya peningkatan penggunaan media ppt $7 \%$, google meet $7 \%$, alat peraga $40 \%$, dan video animasi sebesar $25 \%$. Diharapkan kegiatan pengabdian sejenis dapat dilaksanakan secara berkelanjutan paling tidak setahun sekali. Pelatihan penguasaan media ini sangat diperlukan oleh guru sebagai dasar dalam mengajar seiring dengan perkembangan zaman.

\section{DAFTAR RUJUKAN}

Apak, J., \& Taat, M. S. (2018). Pengaruh Kesediaan Guru terhadap Pengurusan Bilik DarjahAabad ke-21. Malaysian Journal of Social Sciences and Humanities, 3(4), 622. http://msocialsciences.com/index.php/mjssh/article/view/103.

Atsani, K. L. G. M. Z. (2020). Transformasi Media Pembelajaran pada Masa Pandemi COVID-19. Al-Hikmah: Jurnal Studi Islam, 1(1), 82-93. http://ejournal.kopertais4.or.id/sasambo/index.php/alhikmah/article/view/3905.

Baquier Orozco, R., Barraza Castillo, R. I., \& Husted Ramos, S. (2020). Neoaltar: An Interactive Multimedia Day of The Dead Experience. Heliyon. https://doi.org/10.1016/j.heliyon.2020.e03339.

Cucus, A., \& Aprilinda, Y. (2016). Pengembangan E-Learning Berbasis Multimedia untuk Efektivitas Pembelajaran Jarak Jauh. Explore: Jurnal Sistem Informasi Dan Telematika. https://doi.org/10.36448/jsit.v7i1.765.

Firman, F., \& Rahayu, S. (2020). Pembelajaran Online di Tengah Pandemi Covid-19. Indonesian Journal of Educational Science (IJES), 2(2), 81-89. https://ojs.unsulbar.ac.id/index.php/ijes/article/view/659.

Gunawan, G., Harjono, A., Herayanti, L., \& Husein, S. (2019). Problem-Based Learning Approach with Supported Interactive Multimedia in Physics Course: Its Effects on Critical Thinking Disposition. Journal for the Education of Gifted Young Scientists. https://doi.org/10.17478/jegys.627162.

Khasanah, D. R. A. U., Pramudibyanto, H., \& Widuroyekti, B. (2020). Pendidikan dalam 
Masa Pandemi covid-19. Jurnal Sinestesia, 10(1), 41-48. http://sinestesia.pustaka.my.id/journal/article/view/44.

Kurniawati, I. D., \& Nita, S.-. (2018). Media Pembelajaran Berbasis Multimedia Interaktif untuk Meningkatkan Pemahaman Konsep Mahasiswa. Doubleclick: Journal of Computer and Information Technology. https://doi.org/10.25273/doubleclick.v1i2.1540.

Lestari, T., \& Harlinda, S. (2021). Pengaruh Penggunaan WhatsApp terhadap Hasil Belajar IPA Siswa Kelas VA SDN Duri Kepa 03 Jakarta Barat Pada Masa Pandemi. Jurnal Perse, 4(2), 87-92. https://doi.org/https://doi.org/10.37150/perseda.v4i2.1257.

Lestari, T., \& Syofyan, H. (2021). Jurnal perseda. Jurnal Persada, IV(2), 87-92.

Marisda, D. H. (2020). Pembelajaran Konseptual (Interaktive Conceptual Intruction) pada Perkuliahan IPA Terpadu (Nurlina \& Riskawati (eds.); Pertama). LPP Unismuh Makassar.

Marjuni, A., \& Harun, H. (2019). Penggunaan Multimedia Online dalam Pembelajaran. Idaarah: Jurnal Manajemen Pendidikan, 3(2), 194-204. https://scholar.archive.org/work/ntjcydrgqrc7vhytdr5n7es3ha/access/wayback/http://j ournal.uin-alauddin.ac.id/index.php/idaarah/article/download/10015/pdf.

Novayulianti, R. S. H. (2021). Analisis Aktivitas Belajar Siswa pada Mata Pelajaran IPA Kelas V di SDN Duri Kepa 05 Dalam Masa Pandemi Covid-19. Jurnal Inovasi Pendidikan, 2(3), 987-996. https://doi.org/https://doi.org/10.47492/jip.v2i3.793.

Novita, L., Sukmanasa, E., \& Pratama, M. Y. (2019). Penggunaan Media Pembelajaran Video terhadap Hasil Belajar Siswa SD. Indonesian Journal of Primary Education Penggunaan, 3(2), 64-72. https://repository.unpak.ac.id/tukangna/repo/file/files20200110015955.pdf.

Nurrita, T. (2018). Pengembangan Media Pembelajaran untuk Meningkatkan Hasil Belajar Siswa. MISYKAT Jurnal Ilmu-Ilmu Al-Quran Hadist Syari Ah Dan Tarbiyah, 3(1), 171-210. https://pps.iiq.ac.id/jurnal/index.php/MISYKAT/article/view/52.

Parameswari, P., \& Kurniyati, T. (2020). Kemampuan Berpikir Kritis Siswa dalam Memecahkan Masalah Matematika. L Pendidikan Matematika (JPM), 6(2), 89-97. http://riset.unisma.ac.id/index.php/jpm/article/view/6606.

Poerwanti, J. I. S., \& Mahfud, H. (2018). Optimalisasi Penggunaan Media Pembelajaran Interaktif dengan Microsoft Power Point pada Guru-Guru Sekolah Dasar. JPPM (Jurnal Pengabdian Dan Pemberdayaan Masyarakat), 2(2), 265-271. http://jurnalnasional.ump.ac.id/index.php/JPPM/article/view/2296.

Praheto, B. E., Andayani, Rohmadi, M., \& Wardani, N. E. (2020). The Effectiveness of Interactive Multimedia in Learning Indonesian Language Skills in Higher Education. Rupkatha Journal on Interdisciplinary Studies in Humanities. https://doi.org/10.21659/rupkatha.v12n1.34.

Purwanto, A., Pramono, R., Asbari, M., Hyun, C. C., Wijayanti, L. M., \& Putri, R. S. (2020). Studi Eksploratif Dampak Pandemi COVID-19 terhadap Proses Pembelajaran Online di Sekolah Dasar. EduPsyCouns: Journal of Education, Psychology and Counseling, 2(1), 1-12. https://ummaspul.e-journal.id/Edupsycouns/article/view/397.

Putri, S. T., \& Syofyan, H. (2019). Pengaruh Kompetensi Guru Kelas terhadap Minat Belajar Siswa Kelas IV Ppda Mata Pelajaran IPA di Sekolah Dasar Negeri Tanjung Duren Utara 02. Dinamika Sekolah Dasar, 1(1), 1-11.

Rachmadtullah, R., Iasha, V., Rasmitadila, R., \& Sofyan, H. (2019). CD-Based Interactive Multimedia on Integrative Thematic Learning in Elementary School. Prosiding ICTES (First International Conference on Technology and Educational Science). https://doi.org/10.4108/eai.21-11-2018.2282040.

Rachmawati, F., \& Sojanah, J. (2019). Pengaruh Media Pembelajaran dan Komunikasi 
Interpersonal Guru terhadap Minat Belajar Siswa pada Mata Pelajaran Kearsipan di SMKN 1 Bandung. Pendidikan Manajemen Perkantoran, 4(2), 215-227.

Rafiuddin, Basri, M., \& Azis, M. (2017). Urgensi Penggunaan Media dalam Proses Pembelajaran bagi Guru Sekolah Dasar Wilayah II Kecamatan Sanrobone Kabupaten Takalar Provinsi Sulawesi Selatan. Prosiding TEP \& PDs, 2(3), 147-157.

Ratih, \& Syofyan, H. (2021). Pengaruh Penggunaan Media Belajar Powtoon terhadap Motivasi Belajar IPA di Kelas 5 Sekolah Dasar. Perseda, IV(2), 79-86.

Sari, D. S., \& Sugiyarto, K. H. (2015). Pengembangan Multimedia Berbasis Masalah untuk Meningkatkan Motivasi Belajar dan Kemampuan Berpikir Kritis Siswa. Jurnal Inovasi Pendidikan IPA. https://doi.org/10.21831/jipi.v1i2.7501.

Sinta, \& Sofyan, H. (2021). Pengembangan Media Pop-Up Book pada. Jurnal Pendidikan Dasar, 11(2), 245-265.

Syofyan, H., \& Ismail, I. (2018). Pembelajaran Inovatif dan Interaktif dalam Pembelajaran IPA. Qardhul Hasan: Media Pengabdian Kepada Masyarakat. https://doi.org/10.30997/qh.v4i1.1189.

Syofyan, H., \& Yuliana. (2020). Persepsi Guru-Guru tentang Pembelajaran Jarak Jauh ( PJJ ) pada Masa Wabah Virus SARS-CoV-2 di Jakarta. Seminar Nasional Ilmu Pendidikan Dan Multi Disiplin 3 (SNIPMD 3), 3, 380-387.

Wardani, R. K., \& Syofyan, H. (2018). Pengembangan Video Interaktif pada Pembelajaran IPA Tematik Integratif Materi Peredaran Darah Manusia. Jurnal Ilmiah Sekolah Dasar.

Werdiningsih, T., Triyono, M. B., \& Majid, N. W. A. (2019). Interactive Multimedia Learning Based on Mobile Learning for Computer Assembling Subject using the Principle of Multimedia Learning (Mayer). International Journal of Advanced Science and Technology.

Xie, H., Mayer, R. E., Wang, F., \& Zhou, Z. (2019). Coordinating Visual and Auditory Cueing in Multimedia Learning. Journal of Educational Psychology. https://doi.org/10.1037/edu0000285.

Yuliani H, K., \& Winata, H. (2017). Media Pembelajaran Mempunyai Pengaruht terhadap Motivasi Belajar Siswa. Jurnal Pendidikan Manajemen Perkantoran, 2(1), 259-265. https://doi.org/10.17509/jpm.v2i1.14606. 